POLEMIKA

Prof. dr Bogoljub Milosavljević

\title{
POKRAJINSKI STATUT I ORGANIZACIJA POKRAJINSKE VLASTI PREMA USTAVU REPUBLIKE SRBIJE ${ }^{1}$
}

\begin{abstract}
Apstrakt: Pred Ustavnim sudom Srbije pokrenut je postupak za ocenu ustavnosti $i$ zakonitosti Statuta AP Vojvodine. U javnoj raspravi koju je ovaj sud tim povodom organizovao postavljena su dva načelna pitanja: prvo, kakva je pravna priroda $i$ šta je predmet uređivanja pokrajinskog statuta $i$, drugo, da li $i$ na koji način Ustav opredeljuje oblik organizacije pokrajinske vlasti? Na osnovu analize relevantnih ustavnih odredaba, autor zaključuje da pokrajinski statut predstavlja opšti pravni akt koji se u pravnoj hijerarhiji nalazi ispod Ustava $i$ zakona. Primarnu statutarnu materiju predstavlja organizacija pokrajinske vlasti $i$ u tom delu statut po pravilu ne bi potpadao pod ocenu zakonitosti, već samo ustavnosti. Sekundarna statutarna materija (raspodela nadležnosti između pokrajinskih organa $i$ druga pitanja), za razliku od toga, potpadala bi $i$ pod ocenu ustavnosti $i$ zakonitosti. U pogledu drugog pitanja, autor je zauzeo stav da Ustav sadrži niz načela za organizaciju svih javnih vlasti i da sa tim načelima treba da bude usklađena $i$ organizacija pokrajinske vlasti. U okviru tih načela prostire se pravo pokrajine na samoorganizovanje.
\end{abstract}

Ključne reči: Statut AP Vojvodine, Ustav Republike Srbije, statutarna materija, hijerarhija opštih pravnih akata, usaglašenost statuta sa Ustavom i zakonom, organizacija pokrajinske vlasti.

\section{KARAKTER, PREDMET UREĐIVANJA I PRAVNA PRIRODA STATUTA}

Ustavom Republike Srbije (dalje: Ustav) utvrđeno je da je statut najviši pravni akt autonomne pokrajine (član 185. stav 1) i da on mora biti

* Redovni profesor Pravnog fakulteta Univerziteta Union u Beogradu e-mail: bogoljub.milosavljevic@pravnifakultet.rs

1 Ovaj tekst predstavlja delimično stilizovano pravno mišljenje o spornim ustavnopravnim pitanjima u predmetu IUo - 360/2009 - Statut Autonomne pokrajine Vojvodine, koje je autor izložio na javnoj raspravi u Ustavnom sudu Srbije 21. maja 2013. godine. 
saglasan sa Ustavom (član 194. stav 3$)^{2}$ i zakonom (član 195. stav 2), ${ }^{3}$ kao i da ne sme biti u suprotnosti sa potvrđenim međunarodnim ugovorima $i$ opšteprihvaćenim pravilima međunarodnog prava (član 194. stav 5). ${ }^{4}$ Dosledno tome, Ustavni sud je nadležan da odlučuje o "saglasnosti statuta i drugih opštih akata autonomnih pokrajina i jedinica lokalne samouprave sa Ustavom i zakonom" (član 167. stav 1. tačka 4). Ustavom je takođe određen način donošenja (član 185. stav 2$),{ }^{5}$ kao i način objavljivanja i stupanja na snagu pokrajinskog statuta (član 196). ${ }^{6}$

U pogledu predmeta statutarnog uređivanja, Ustav ne sadrži potpunu odredbu, već neposredno imenuje samo jedno takvo pitanje (član 187) i navodi određena pitanja za koja se može sa izvesnošću zaključiti da spadaju u taj predmet (član 179. i član 183. stav 1). Prema članu 187, statutom autonomne pokrajine određuje se organ koji ima pravo žalbe Ustavnom sudu, odnosno koji može pokrenuti postupak za ocenu ustavnosti i zakonitosti radi zaštite pokrajinske autonomije. ${ }^{7} \mathrm{U}$ članu 179. propisano je da autonomne pokrajine, u skladu sa Ustavom i svojim statutom, samostalno propisuju uređenje i nadležnost svojih organa i službi. ${ }^{8}$ Prema stavu 1. člana 183, autonomne pokrajine, u skladu sa Ustavom i svojim statutom, uređuju nadležnost, izbor, organizaciju i rad organa i službi koje osnivaju. ${ }^{9}$ Između odredaba ova dva člana postoji razlika ne samo u pogledu precizi-

2 „Svi zakoni i drugi opšti akti u Republici Srbiji moraju biti saglasni sa Ustavom.”

3 „Statuti, odluke i svi drugi opšti akti autonomnih pokrajina i jedinica lokalne samouprave moraju biti saglasni sa zakonom.”

4 „Zakoni i drugi opšti akti doneti u Republici Srbiji ne smeju biti u suprotnosti sa potvrđenim međunarodnim ugovorima i opšteprihvaćenim pravilima međunarodnog prava."

5 „Statut autonomne skupštine donosi njena skupština, uz prethodnu saglasnost Narodne skupštine.”

6 „Zakoni i svi drugi opšti akti objavljuju se pre stupanja na snagu” (stav 1). „Ustav, zakoni i podzakonski akti Republike Srbije objavljuju se u republičkom službenom glasilu, a statuti, odluke i drugi opšti akti autonomnih pokrajina objavljuju se u pokrajinskom službenom glasilu” (stav 2). „Zakoni i drugi opšti akti stupaju na snagu najranije osmog dana od dana objavljivanja i mogu da stupe na snagu ranije samo ako za to postoje naročito opravdani razlozi, utvrđeni prilikom njihovog donošenja” (stav 4).

7 „Organ određen statutom autonomne pokrajine ima pravo žalbe Ustavnom sudu ako se pojedinačnim aktom ili radnjom državnog organa ili organa jedinice lokalne samouprave onemogućava vršenje nadležnosti autonomne pokrajine” (stav 1). „Organ određen statutom autonomne pokrajine može pokrenuti postupak za ocenu ustavnosti ili zakonitosti zakona i drugog opšteg akta Republike Srbije ili opšteg akta jedinice lokalne samouprave kojim se povređuje pravo na pokrajinsku autonomiju" (stav 2).

8 „Autonomne pokrajine, u skladu sa Ustavom i statutom autonomne pokrajine, a jedinice lokalne samouprave, u skladu sa Ustavom i zakonom, samostalno propisuju uređenje i nadležnost svojih organa i javnih službi."

9 „Autonomne pokrajine, u skladu sa Ustavom i svojim statutom, uređuju nadležnost, izbor, organizaciju i rad organa i službi koje osnivaju." 
ranja izvršenog u stavu 1. člana $183^{10}$ već i u izostavljanju reči „samostalno" u istoj odredbi. U obe odredbe se, međutim, ne kaže direktno da se statutom propisuju, odnosno uređuju navedena pitanja, već da autonomna pokrajina to čini „u skladu sa Ustavom i svojim statutom”. Obe odredbe, dakle, na indirektan način utvrđuju da ta pitanja jesu statutarna materija, ali ne samo statutarna. O značenju određenja „samostalno” se takođe može diskutovati, budući da u donošenju statuta učestvuje volja Narodne skupštine. Važnija od tog pitanja (koje se i nije postavilo kao sporno) jeste činjenica da Ustav samo implicitno upućuje na sadržinu pokrajinskog statuta u nekim svojim drugim odredbama, naročito u odredbama člana 183.

Iz navedenih ustavnih odredaba moglo bi se zaključiti sledeće:

(1) Statut autonomne pokrajine je specifičan opšti pravni akt koji se donosi u naročitoj, Ustavom propisanoj proceduri, i koji ima, prema samom Ustavu, karakter najvišeg pravnog akta autonomne pokrajine.

(2) Prema Ustavom utvrđenoj hijerarhiji opštih pravnih akata, statut autonomne pokrajine se nalazi ispod zakona, tako da mora biti saglasan sa Ustavom i zakonom, a ne sme biti u suprotnosti sa potvrđenim međunarodnim ugovorima i opšteprihvaćenim pravilima međunarodnog prava. Iako se nalazi ispod zakona, statut svakako nije običan podzakonski akt. Naime, uređujući hijerarhiju pravnih akata, ustavotvorac je u članu 195. stav 2. posebno imenovao „statute, odluke i sve druge opšte akte autonomnih pokrajina i jedinica lokalne samouprave" i utvrdio da oni moraju biti saglasni sa zakonom. Zanimljivost može činiti to što je u prethodnom stavu (stav 1) istog člana najpre postavljen zahtev u pogledu saglasnosti podzakonskih akata sa zakonom. Iz ove činjenice, kao i iz tradicionalnog pravničkog stava prema kome se svi opšti pravni akti mogu razdeliti na ustav, zakone i podzakonske akte, ipak se ne bi moglo zaključiti da je pokrajinski statut tek običan podzakonski akt. Ako bi se to prihvatilo, usledila bi i mogućnost ocene saglasnosti čitavog statuta sa zakonom, što inače neki smatraju kao ispravan stav. Međutim, ako bi se takav stav prihvatio, otvorilo bi se pitanje smisla i održivosti ustavne odredbe prema kojoj se statutom, a „u skladu sa Ustavom”, uređuju pitanja nadležnosti, izbora, organizacije i rada pokrajinskih organa i službi (član 183. stav 1). Već u narednom stavu istog člana dikcija je izmenjena: tu se kaže da pokrajine, $u$ skladu sa zakonom, uređuju pitanja od pokrajinskog značaja u određenim oblastima. Mišljenja sam, dakle, da se

10 Član 179. govori o „uređenju i nadležnosti”, a član 183. stav 1. govori o uređenju „nadležnosti, izbora, organizacije i rada organa i službi” koje autonomne pokrajine osnivaju. 
zakonitost statuta može ocenjivati ukoliko predmet njegovog uređivanja izlazi iz okvira statutarnih pitanja, preciznije, ako on zalazi u materiju pokrajinske nadležnosti, o čemu se dalje govori.

(3) Primarnu statutarnu materiju predstavlja „uređenje vlasti” u autonomnoj pokrajini, odnosno propisivanje nadležnosti, izbora, organizacije i rada pokrajinskih organa i službi. Jezičkim i logičkim tumačenjem člana 179. i člana 183. stav 1 . može se zaključiti da se statutarnim odredbama uređenje tih pitanja ne iscrpljuje, već da autonomna pokrajina „u skladu sa Ustavom i svojim statutom” ta pitanja uređuje (i) u drugim pokrajinskim opštim aktima. Mada se to meni čini dovoljno jasnim, s tim u vezi je možda potrebno naglasiti da se ustavno ovlašćenje na uređivanje nadležnosti isključivo odnosi na raspodelu ustavnog i zakonskog korpusa nadležnosti autonomne pokrajine između pojedinih pokrajinskih organa i službi, a ne na utvrđivanje tog korpusa u statutu (on se može utvrđivati samo ustavom i zakonom). Naime, da se pokrajinske nadležnosti mogu utvrđivati ustavom (na opšti ili konkretniji način) i potom operacionalizovati samo zakonom, a ne i pokrajinskim aktima, sasvim izgleda jasno i saglasno prirodi autonomije. ${ }^{11}$ Ipak, u Statutu Autonomne pokrajine Vojvodine nepotrebno se ponavljaju sve pokrajinske nadležnosti (osporeni član 29. Statuta), da bi se potom one raspodeljivale između pokrajinskih organa i službi.

(4) Pored navedene - primarne materije, statutom autonomne pokrajine mogu se uređivati i druga pitanja, od kojih se neka mogu implicitno izvesti iz teksta Ustava. Koliko će takvih pitanja biti uređeno, zavisilo bi načelno od procene donosilaca statuta - skupštine autonomne pokrajine i Narodne skupštine, s tim što je ta procena dvostruko ograničena: (1) odredbama Ustava (koje se odnose na pojedina od tih pitanja) i (2) nadležnostima autonomne pokrajine, odnosno nadležnostima Republike Srbije, s jedne, i jedinica lokalne samouprave, $s$ druge strane. Razume se da i karakter statuta kao najvišeg pravnog akta autonomne pokrajine podrazumeva adekvatnu meru u uređivanju (u smislu ostavljanja prostora za druge opšte pravne akte). Osim toga, takva pitanja bi morala biti uređena tako da se izbegne kolizija sa zakonom, odnosno da njihovo uređivanje bude saglasno zakonu. Sva takva pitanja bi, dakle, bez dileme potpadala ne samo pod ocenu ustavnosti, već i pod ocenu zakonitosti. Ova „druga pitanja” uslovno bismo mogli označiti

11 O tome je Ustavni sud zauzeo stavove u predmetu IUz-353/2009, povodom ocene ustavnosti Zakona o nadležnostima Autonomne pokrajine Vojvodine. Komentar te odluke videti u članku: Milosavljević, B., 2012, Ustavnopravni koncept teritorijalne autonomije u Srbiji, Pravni život, 12, str. 835-848. 
sekundarnom statutarnom materijom, i to nikako da bi se naglasio njen manji značaj, već isključivo da bismo je razlikovali od primarne statutarne materije kojoj i sam Ustav daje naročiti karakter označavajući je kao posebno pravo i element pokrajinske autonomije.

(5) Ostaje stoga kao najspornije pitanje ono o karakteru dela statutarne materije koju smo označili kao primarnu i koja se odnosi na „uređenje vlasti”, odnosno na uređenje pokrajinskih organa i službi. Suština ovog spora sa stanovišta ustavnih normi, i to onako kako je viđena u Predlogu za ocenu ustavnosti Statuta Autonomne pokrajine Vojvodine, mogla bi da bude u pravnom smislu svedena na tumačenje međusobnog odnosa između odredaba člana 179. i člana 183. stav 1, s jedne, i člana 195. stav 2, s druge strane. Prema prvim odredbama (tj. član 179. i član 183. stav 1), autonomna pokrajina samostalno propisuje uređenje i nadležnost (odnosno nadležnost, izbor, organizaciju i rad svojih organa i službi) u skladu sa Ustavom i svojim statutom. Međutim, odredbom člana 195. stav 2. postavljen je nedvosmislen zahtev da statut autonomne pokrajine (u pogledu svih njegovih odredaba) bude saglasan ne samo Ustavu, nego i zakonu. Ako bi se dala prednost ovoj drugoj ustavnoj normi, logičan odgovor bi glasio da primarna statutarna materija mora biti usaglašena ne samo sa Ustavom već i sa zakonom. Po istoj logici bi Republika Srbija mogla da svojim zakonima propiše sve elemente uređenja pokrajinskih organa i službi. Međutim, takav odgovor bi značio negaciju norme o pravu autonomne pokrajine na samostalno uređivanje svojih organa koju ustavna odredba utvrđuje u članu 179. i ponavlja u članu 183. stav 1. Šta onda zapravo znači pravo autonomne pokrajine na samostalno uređivanje svojih organa i da li se ono realizuje samo u skladu sa Ustavom ili i u skladu sa zakonom? Na ovo pitanje daje se jedan mogući i po mom mišljenju ustavnopravno prihvatljiv odgovor u narednom odeljku.

\section{ORgANIZACIJA POKRAJINSKE VLASTI}

Utvrđujući pravo autonomne pokrajine na samostalno uređivanje svojih organa, Ustav je istovremeno to pravo ograničio na taj način što je postavio dva jasna zahteva, od kojih je jedan opštiji, a drugi sasvim konkretan. Prvi zahtev se odnosi na to da uređenje vlasti u autonomnoj pokrajini, i to u celini - u svim elementima - bude u saglasnosti sa Ustavom. Drugi i konkretniji zahtev je postavljen u članu 180. i tiče se uređenja skupštine autonomne pokrajine. Iz ovoga sledi da čitavo uređenje pokrajinskih organa mora da bude saglasno određenim ustavnim principima, 
a u slučaju pokrajinske skupštine da bude saglasno kako tim principima, tako i odredbama člana $180 . .^{12}$

U praktičnom pogledu, prvi od dva navedena ustavna zahteva je teži za primenu jer zahteva određena tumačenja brojnih mesta u Ustavu. Naime, u delu Ustava posvećenom teritorijalnom uređenju nisu sadržani neki od bitnih principa za uređenje vlasti, niti na drugom mestu u Ustavu postoji posebno izdvojeni skup principa koji bi se odnosili na organizaciju vlasti na svim nivoima njenog organizovanja (dalje: javne vlasti). U delovima Ustava o ljudskim i manjinskim pravima i slobodama, o ekonomskom uređenju i javnim finansijama i o ustavnosti i zakonitosti sadržani su pojedini takvi principi, odnosno neka od konkretnih pravila za organizaciju svih javnih vlasti. U Osnovnim načelima Ustava postoje principi za koje se u pojedinim slučajevima očigledno može utvrditi da se odnose samo na državnu vlast, a u drugim slučajevima na sve nivoe javnih vlasti. I u delu Ustava koji uređuje državnu vlast (Peti deo) nalaze se pojedine odredbe koje se odnose na sve nivoe javnih vlasti, na primer takvog je karaktera odredba o javnim službama u članu 137. st. 4. i 5. Iz Četvrtog i Petog dela Ustava, kao i iz odredaba Ustava o lokalnoj samoupravi, proizlazi i svojevrsna "negativna klauzula”, odnosno nemogućnost da autonomna pokrajina formira identične organe vlasti i dodeli im funkcije koje su rezervisane za Republiku Srbiju, odnosno za lokalnu samoupravu.

Mada bi izloženi i još uvek dosta uopšteni stavovi zahtevali dalju konkretizaciju, čini mi se nespornim da uređenje vlasti u autonomnoj pokrajini ne može biti u nesaglasnosti, odnosno u suprotnosti sa principima kakvi su oni sadržani u članu 1. Ustava (vladavina prava, socijalna pravda, načela građanske demokratije, ljudska i manjinska prava i slobode i pripadnost evropskim principima i vrednostima), zatim sa principom građanske suverenosti i poluneposredne demokratije (koji je, osim u članu 2, posebno utvrđen i u članu 176. stav 1), kao i sa načelima političkog pluralizma, zabrane sukoba interesa, službene upotrebe jezika i pisma, svetovnosti države, zaštite nacionalnih manjina, ravnopravnosti polova i dr. Ovaj bi se stav na isti način odnosio i na druge pomenute delove Ustava.

U Ustavu postoji, prema tome, jedan skup normi koji pruža osnove za uređenje svih javnih vlasti i koji se otuda podjednako odnosi na ure-

12 Član 180. glasi: „Skupština je najviši organ autonomne pokrajine i jedinice lokalne samouprave” (stav 1). „Skupštinu autonomne pokrajine čine poslanici, a skupštinu jedinice lokalne samouprave odbornici” (stav 2). „Poslanici i odbornici biraju se na period od četiri godine, na neposrednim izborima tajnim glasanjem, i to poslanici u skladu sa odlukom skupštine autonomne pokrajine, a odbornici, u skladu sa zakonom” (stav 3). „U autonomnim pokrajinama i jedinicama lokalne samouprave u kojima živi stanovništvo mešovitog nacionalnog sastava, omogućuje se srazmerna zastupljenost nacionalnih manjina u skupštinama, u skladu sa zakonom” (stav 4). 
đenje državne vlasti, pokrajinske vlasti i lokalnih vlasti. Na tim osnovama, kao elementima sistema javnih vlasti, detaljnije je uređena državna vlast u Ustavu, odnosno uređeni su najvažniji (ustavni) organi vlasti, uz delegiranje niza pitanja organskim zakonima. Iste te osnove, uz posebne ustavne odredbe o teritorijalnom uređenju, vrede i za uređenje pokrajinske i lokalne vlasti, s tim što u slučaju pokrajinske vlasti Ustav utvrđuje pravo detaljnijeg uređivanja kao zakonom neuslovljeno pravo na samoorganizovanje, tj. u korist pokrajinskog statuta i drugih pokrajinskih propisa (a ne i zakonodavca). Za razliku od toga, u slučaju lokalnih vlasti ovo isto pravo (na samoorganizovanje) učinjeno je zavisnim od volje zakonodavca. S tim u vezi, svestan sam da u ovom mišljenju nisam dao precizne sastavne delove onog što sam nazvao „osnovama uređenja javnih vlasti” i „elementima sistema javnih vlasti”, ali sam ubeđen da je tako nešto izvodljivo i da ustavni sistem svake zemlje na tome počiva. Onaj šire postavljeni zahtev, prema kome uređenje pokrajinske vlasti mora biti u celini u skladu sa Ustavom, po mom mišljenju ne znači samo zahtev za usaglašenošću sa delom Ustava o teritorijalnom uređenju, već i zahtev za saglasnošću sa čitavim Ustavom - svim njegovim odredbama koje se tiču uređenja javnih vlasti, a koje sadrže Osnovna načela i delovi Ustava o ljudskim pravima, ekonomskom uređenju i ustavnosti i zakonitosti. Ovaj zaključak, sa druge strane, nipošto ne podrazumeva zahtev po kome bi nužno postojala istovetnost ili monotipnost $u$ uređenju organa javnih vlasti na svim nivoima, već samo poštovanje istih osnovnih principa.

$\mathrm{Na}$ osnovu izloženog mogli bi se izvesti sledeći konkretniji stavovi od značaja za Statutom Autonomne pokrajine Vojvodine uspostavljenu organizaciju vlasti i ocenu ustavnosti osporenih odredaba koje se na to pitanje odnose:

(1) Odredbama člana 180. Ustava uređuje se da je skupština najviši organ autonomne pokrajine, da je čine poslanici koji se biraju na period od četiri godine, na neposrednim izborima tajnim glasanjem, i to u skladu sa odlukom skupštine autonomne pokrajine, kao i da se u skupštini omogućuje srazmerna zastupljenost nacionalnih manjina, u skladu sa zakonom. ${ }^{13}$ Osim što je utvrđeno da je pokrajinska skupština najviši pokrajinski organ, druga pitanja njenog položaja i odnosa sa pokrajinskom vladom nisu Ustavom regulisana (usput valja primetiti da se u članu 126. stav 1. Ustava ne govori o pokrajinskoj vladi, već o „izvršnom veću autonomne pokrajine"). Samo u jednoj odredbi Ustava (član 107. stav 1) utvrđuje se jedna od nadležnosti skupštine autonomne pokrajine

13 Na poslanike pokrajinske skupštine odnose se izričito i ustavne odredbe o nespojivosti funkcija (član 102. stav 3. i član 126. stav 1). 
(pravo zakonodavne inicijative). Ustavom nije opredeljen ni oblik odnosa između pokrajinske skupštine i pokrajinske vlade, za razliku od odnosa između Narodne skupštine i Vlade koji su uspostavljeni prema parlamentarnom obrascu organizacije vlasti. Moglo bi se ustvrditi da načelo podele vlasti pripada onoj kategoriji ustavnih principa koji predstavljaju element čitavog sistema javnih vlasti, te da bi i odnosi između pokrajinske skupštine i njenog izvršnog organa trebalo da budu uređeni na tom načelu. Kako je primena tog načela moguća $u$ više oblika, to se može konstatovati da je u uređenju odnosa između pokrajinske skupštine i njenog izvršnog organa moguće primeniti bilo koji od tih oblika, a najpre neki od podoblika parlamentarnog obrasca. $S$ tim u vezi, nisam saglasan sa nekim tvrdnjama predlagača, prema kojima Ustav utvrđuje skupštinski sistem organizacije vlasti za autonomne pokrajine.

(2) Osim odredaba o pokrajinskoj skupštini i spomenutog pominjanja „izvršnog veća autonomne pokrajine”, u Ustavu se ne govori ni o jednom drugom pokrajinskom organu. Za te druge organe vredela bi samo ograničenja utvrđena ustavnim principima. Podsetimo se ponovo izuzetka u pogledu javnih službi, kod kojih stvar stoji bitno drugačije, s obzirom na član 137. st. 4. i 5. ${ }^{14}$

(3) Pravo autonomne pokrajine na samostalno uređivanje svojih organa postavljeno je u Ustavu kao pravo koje ima prostranu širinu. Ono je ograničeno samo u pogledu pokrajinske skupštine, i to odredbama člana 180. i principima Ustava, dok je u pogledu ostalih organa ograničeno samo principima Ustava. Konkretnije, to pravo autonomne pokrajine obuhvata:

(3.1) Pravo uređivanja nadležnosti pokrajinskih organa (tj. raspoređivanja normativnih, izvršnih, upravnih i drugih poslova između pokrajinskih organa, u okviru pokrajinskih nadležnosti). Međusobni odnosi između tih organa, kao što je već rečeno, trebalo bi da budu uređeni tako da skupština ima položaj najvišeg organa, dok bi njen odnos sa izvršnim organom trebalo da se odvija u okvirima nekog od podoblika parlamentarnog obrasca.

(3.2) Pravo uređivanja izbora pokrajinskih organa pripada autonomnoj sferi uređivanja, ali uz poštovanje ustavnih normi iz člana 180, kao i odnosnih političkih prava građana i principa Ustava (na primer, o ulozi političkih stranaka). Tip izbornog

14 „Republika Srbija, autonomne pokrajine i jedinice lokalne samouprave mogu osnovati javne službe (stav 4). „Delatnosti i poslovi zbog kojih se osnivaju javne službe, njihovo uređenje i rad propisuju se zakonom" (stav 5). 
sistema inače nije opredeljen Ustavom ni za izbor narodnih poslanika, pa je autonomna pokrajina slobodna da izabere tip tog sistema kakav smatra prikladnim. U članu 180. stav 4. postavljen je i važan izuzetak od pravila da autonomna pokrajina u skladu sa Ustavom uređuje izbor i sastav skupštine, na taj način što se pitanje srazmerne zastupljenosti nacionalnih manjina uređuje zakonom.

(3.3) Pravo uređivanja organizacije pokrajinskih organa i načina njihovog rada takođe podrazumeva prostranu autonomnu sferu, ali i potpada pod obavezu poštovanja ustavnih principa o organizaciji i radu svih organa javnih vlasti.

(4) Pošto iz Ustava sledi da zakon ne može uređivati materiju organizacije pokrajinske vlasti (primarnu statutarnu materiju), to znači da ni pokrajinski statut u ovom svom delu ne treba ocenjivati sa stanovišta zakona, već samo sa stanovišta Ustava. Izuzetak bi predstavljao slučaj u kome je sam Ustav odredio da će se neko od takvih pitanja uređivati statutom ne samo u skladu sa Ustavom, već i u skladu sa zakonom. Takvo bi pitanje potpadalo pod ocenu zakonitosti. Izvan takvog slučaja zakonodavac bi svojim uređivanjem organizacije pokrajinske vlasti povređivao Ustav, pa bi eventualne takve zakone trebalo osporavati sa stanovišta povrede prava na pokrajinsku autonomiju (u smislu člana 187. stav 2).

(5) U pogledu međusobnog odnosa između odredaba člana 179. i člana 183. stav $1, \mathrm{~s}$ jedne, i člana 195. stav 2 , s druge strane, mišljenja sam da bi taj odnos trebalo protumačiti upravo na izloženi način. Statut autonomne pokrajine bi, po mom mišljenju, potpadao pod ocenu ustavnosti i zakonitosti u delu koji sam označio kao njegovu sekundarnu sadržinu. Za razliku od toga, ona statutarna materija koju sam označio kao primarnu statutarnu materiju, mogla bi se ocenjivati samo iz ugla saglasnosti sa Ustavom (ocena ustavnosti), dok bi se kao izuzetna mogućnost koristila i ocena zakonitosti u slučaju kada je samim Ustavom propisano da se neko od pitanja iz domena organizacije pokrajinske vlasti uređuje i zakonom.

Dostavljeno Redakciji: 1. novembra 2013. god.

Prihvaćeno za objavljivanje: 18. novembra 2013. god. 